\title{
H1N1 infection in Pregnancy: clinical course in two women
}

\author{
Gebelikte H1N1 enfeksiyonu: Iki hastada klinik seyir
}

\author{
Aysun Karabulut ${ }^{1}$, Alpaslan Çalışkan ${ }^{1}$, Ferzan Göncü², Samet Uyar ${ }^{3}$, Murat Kutlu ${ }^{2}$ \\ 'Department of Obstetrics and Gynecology, Denizli State Hospital, Denizli, Turkey \\ ${ }^{2}$ Department of Infectious Diseases, Denizli State Hospital, Denizli, Turkey \\ ${ }^{3}$ Department of Cardiology, Denizli State Hospital, Denizli, Turkey
}

\section{Abstract}

Pregnant women are one of the major risk groups for disease related morbidity and mortality from influenza A (H1N1, swine flu) pandemic. Healthy pregnant women are supposed to have 4 to 5 fold increased rate of serious illness and hospitalization compared to non-pregnant subjects. Herein, the clinical course of novel influenza A (H1N1) infection in two pregnant women was presented. One woman expired due to delay in treatment, while the other one was discharged on day six after prompt treatment. We would like to emphasize that obstetricians should be aware of the clinical and radiological manifestations of influenza A for prompt diagnosis and treatment. Obstetricians also should prepare themselves to provide adequate care for pregnancy related complications encountered by pregnant women with H1N1 infection. (J Turkish-German Gynecol Assoc 2011; 12: 118-20)

Key words: H1N1, influenza, pregnancy, oseltamivir

Received: 22 May, 2010

Accepted: 5 August, 2010
Özet

Gebe kadınlar influenza A (H1N1) pandemisinde hastalığa bağlı morbidite ve mortalitede major risk grubudur. Sağlıklı gebe kadınların gebe olmayanlara göre ciddi hastalık geçirme ve hasteneye yatırılma oranlanın 4-5 kat daha fazla olduğu tahmin edilmektedir. Bu çalışmada, influenza A virüsünün iki gebe kadında gösterdiği klinik seyrin sunulması amaçlandı. Bir kadın tedavideki geçikmeye bağlı kaybedilirken, diğeri tedavinin hemen başlanması sayesinde altıncı gün taburcu edildi. Çalışmada obstetrisyenlerin influenza A'nın hızlı tanı ve tedavisi için hastalığın klinik ve radyolojik bulgularının farkında olmalarının önemi vurgulamak istedik. Obstetrisyenler tanının yanısıra, H1N1 enfekte gebede gelişebilecek gebeliğe bağlı komplikasyonların tedavisi için de hazırlıklı olmalıdır.

(J Turkish-German Gynecol Assoc 2011; 12: 118-20)

Anahtar kelimeler: H1N1, influenza, gebelik, oseltamivir

Geliş Tarihi: 22 Mayıs 2010

Kabul Tarihi: 05 Ağustos 2010

\section{Introduction}

Pregnant women are one of the major risk groups for disease related morbidity and mortality from the 2009 influenza A (H1N1, swine flu) pandemic (1). Healthy pregnant women are supposed to have 4 to 5 fold increased rate of serious illness and hospitalization with influenza (2-5).

In April 2009, the first cases of a severe pneumonia like illness affecting mostly healthy people began to be reported from Mexico (1). In May 2009, the centers of Disease Control and Prevention in the United States released a report documenting severe complications of influenza A in pregnant women including 20 confirmed cases and one death. To our knowledge there are a few case series of pregnant women infected with H1N1 reported previously in the literature (6-8) and there were no cases reported from Turkey. In this report, we present the different clinical courses of novel influenza A (H1N1) infection in two pregnant women with emphasis on the prompt treatment.

\section{Case Reports}

Case 1

A 36-year-old female with a 29 weeks twin pregnancy was admitted to the obstetric clinic with the complaint of vaginal

bleeding during coughing. A productive cough had been present for two days. Her vital signs at admission were: pulse rate 84 per minute, blood pressure $110 / 70 \mathrm{~mm} \mathrm{Hg}$, temperature $36.5^{\circ} \mathrm{C}$. She had irregular contractions of the uterus, at 5 to 10 minutes intervals. On ultrasonography, a di-amniotic and mono-chorionic twin pregnancy with low lying placenta near the internal cervical os was present. There was no cervical dilatation. Intravenous ritodrin therapy $0.3 \mathrm{mg} / \mathrm{min}$ was given for 24 hours. The next day she had no contractions, no fever, babies were well on sonography. On hospital day three, the cough progressively worsened, and the patient became dyspneic and had a fever of $38^{\circ} \mathrm{C}$. She was sent for consultation to the department of internal medicine and infectious diseases. Physical examination was remarkable for bi-basilar pulmonary crackles, and third degree systolic murmur on auscultation. Her chest X-ray revealed bilateral multifocal areas of consolidation consistent with pneumonia (Fig. 1). Second degree mitral and third degree tricuspid insufficiency were detected on echocardiography. On the suspicion of influenza A, a nasal swab was obtained and oseltamivir was recommended after explaining the risks and benefits. She rejected the treatment with oseltamivir. Ceftazidime pentahydrate and budesonide were started. On admission day four, heavy vaginal bleeding occurred suddenly and the fetal heart sounds of one of the 
babies could not be detected. Sonography confirmed that one of the fetuses was dead, and the other was alive. Emergency cesarean section was performed. A female infant weighing 1100 gr with Apgar scores of 5 and 6 ( 1 and 5 minutes respectively) and a dead female fetus of 1020 gr were delivered. A broad hematoma extending from the prevesical area to the ileocecal region was detected. It was thought to be due to excessive heavy coughing. After operation, her condition continued to deteriorate and she was transferred to the intensive care unit. Mechanical ventilation with high $\mathrm{FiO}_{2}$ and high PEEP was applied to maintain proper oxygenation. The diagnosis of H1N1 influenza was confirmed by polymerase-chain-reaction. Oseltamivir phosphate and levofloxacin were added to the treatment protocol. However, the patient expired on the sixth day after admission due to sepsis and progressive Adult respiratory distress syndrome (ARDS).

\section{Case 2}

A 30-year-old pregnant woman at 32 weeks gestation was admitted to the infectious disease outpatient clinic with fever, sore throat and productive cough that had been present for 2 days. On admission, vital signs included a pulse rate of 112 per minute, blood pressure of $110 / 80 \mathrm{~mm} \mathrm{Hg}$, temperature of $38.5^{\circ} \mathrm{C}$. Physical examination was notable for hyperemia of the pharynx and bilateral pulmonary crackles. Bilateral multifocal air space consolidation was detected on chest X-ray (Fig. 2). Because of the ongoing epidemic of influenza A, a nasal swab was obtained and the patient was isolated. Oseltamivir phosphate and ampicilin clavulanic acid were started for treatment, after the patient was informed of the risks and benefits of the drugs. The diagnosis was confirmed by polymerase-chain-reaction two days later. On admission day 4, cough and production of sputum were decreased, and fever disappeared. On day 5 , she was discharged on her own demand. No problem was detected for the patient and her baby on the follow up one week after discharge. She was uneventfully delivered at 38 weeks of pregnancy.

\section{Discussion}

Two cases presented in this report demonstrate variability in the course of the novel influenza A (H1N1) infection in pregnant women. In the first case, antiviral therapy was delayed due to rejection of the patient. ARDS developed in a short time, leading to a catastrophic outcome. In the second case, treatment was started early, and the disease was resolved in five days. The 2009 H1N1 influenza can cause severe illness and death in pregnant women. Preexisting co-morbidities may further increase the morbidity and mortality. In our first case, there was nothing remarkable in the previous history, but cardiac valvular insufficiency was detected during the work up. It might have contributed to the rapid deterioration of the patient. In our second case, the treatment was started early, just after admission, whereas in the first case the treatment was delayed until the $4^{\text {th }}$ day of admission. Obstetricians should be aware of the clinical and radiological manifestations of novel H1N1 influenza. Sore throat, fever, myalgia, cough, shortness of breath and history of

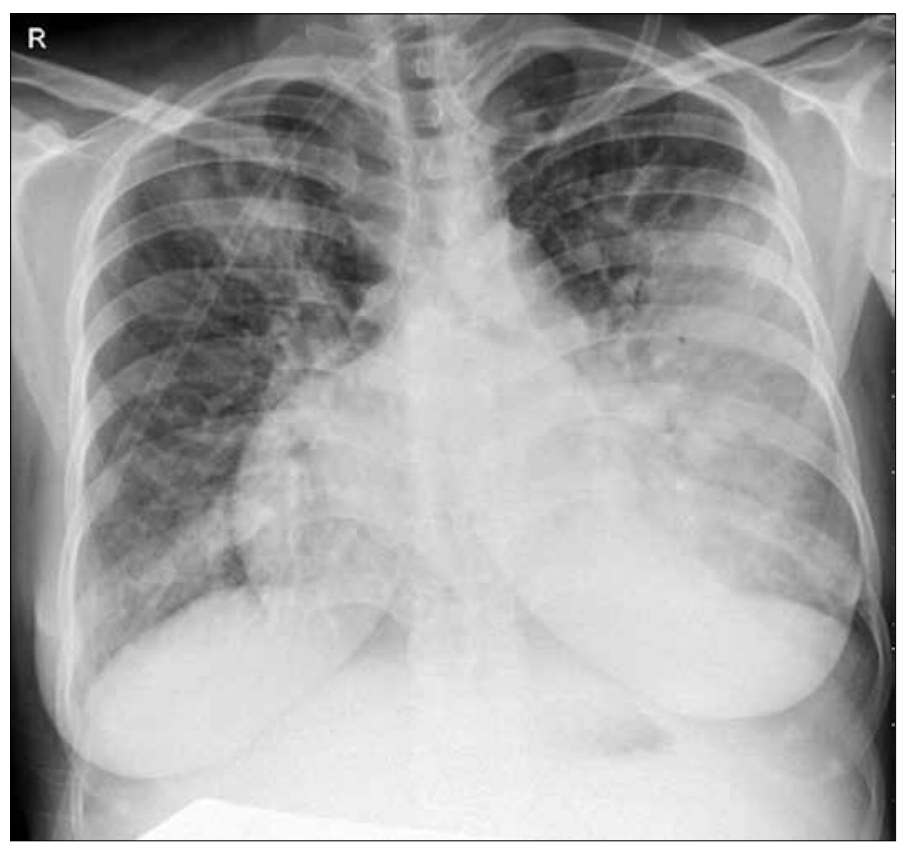

Figure 1. PA Chest X-ray shows bilateral multifocal areas of consolidation, with left middle and lower lung zones predominant

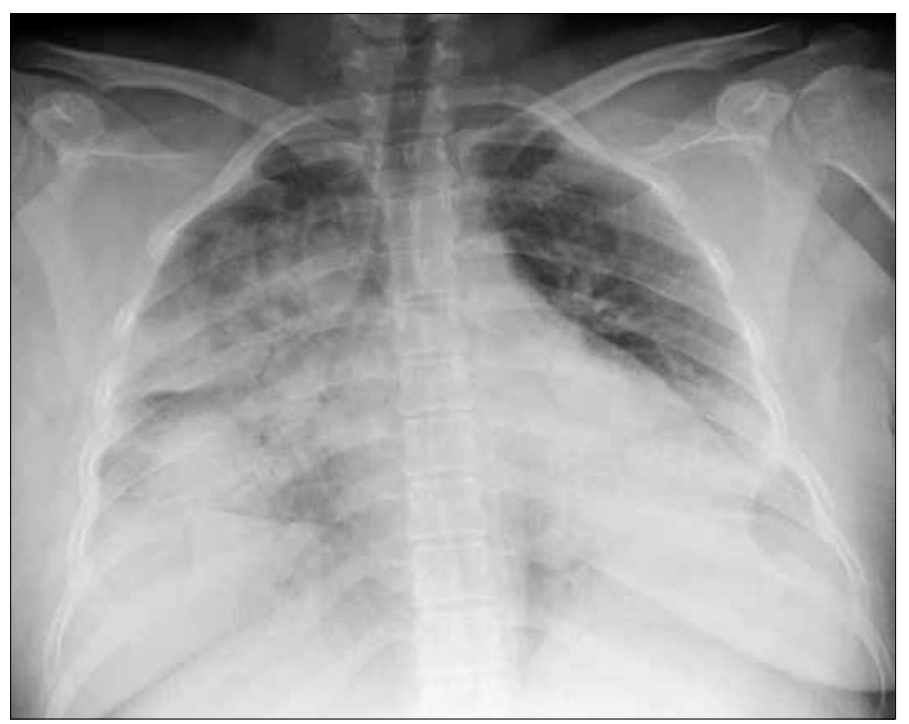

Figure 2. PA chest X-ray shows bilateral consolidation particularly in the middle and lower zones of the right lung, and lower zone of the left lung

household contact are the alarming signs, but some of these signs may be attributable to pregnancy. It causes delays in the initiation of therapy. Therefore, novel H1N1 influenza must be kept in mind in pregnant women with suggestive clinical findings, and treatment must be started promptly in suspected cases. Prompt diagnosis with early initiation of antiviral treatment is critical in pregnant patients with $\mathrm{H} 1 \mathrm{~N} 1$ influenza. The centers for Disease Control and Prevention (CDC) recommends prompt antiviral therapy in suspected and confirmed cases, preferably in the first 48 hours (3). In a recent series of 94 pregnant women reported from California, USA, it was stated that pregnant women 
who received treatment after 48 hours had approximately four fold increased risk of admission to intensive care unit or death compared to those who received treatment earlier (9). Therefore, antiviral therapy should be started as soon as possible on clinical presentation of fever, sore throat and cough without waiting for the laboratory results and the patient should be persuaded to prevent delays as in our case (9). Oseltamivir and zanamivir can both be used in pregnancy and neither of them are teratogenic (9). Since more data was available for oseltamivir, it was usually preferred in pregnant women. The subject of teratogenicity must be clarified to convince patients. The benefit of the treatment overweighs the risk for the fetus (10). The treatment should preferably be started in first 48 hours and continued for five days ( $75 \mathrm{mg}$ Oseltamivir $2 \mathrm{x} 1$ ). For post-exposure chemo-prophylaxis, 10 days of $75 \mathrm{mg}$ Oseltamivir once a day was recommended by CDC (10).

According to the January 2010 report of Turkish Ministry of Health, forty women died during pregnancy and puerperal period due to H1N1 influenza (11). Immunization is the only means of protection against H1N1 infection. Because pregnant women form one of the high risk groups, they should be encouraged to be vaccinated. Maternal vaccination generates an immune response and decreases the risk of infection in the mother and the infant up to the six month after delivery. Vaccination for pregnant women was introduced to the public in early December 2009 in our country, with a strong recommendation to all pregnant women for the sake of both mother and fetus (1).

In conclusion, pregnant women are a risk group for influenza A. The disease may progress rapidly with high morbidity and mortality in pregnant patients. Prompt diagnosis with early treatment is critical for a better outcome.

\section{Conflict of interest}

No conflict of interest was declared by the authors.

\section{References}

1. Carlson A, Thung SF, Norwitz ER. H1N1 Influenza in Pregnancy: What All Obstetric Care Providers Ought to Know. Rev Obstet Gynecol 2009; 2: 139-45.

2. Pregnant women and novel influenza A (H1N1): considerations for clinicians. Centers for Disease Control and Prevention Web site. http://www.cdc.gov/h1n1flu/clinician_pregnant.htm. Updated June 30, 2009. Accessed August 24, 2009.

3. Centers for Disease Control and Prevention (CDC). Novel influenza A (H1N1) virus infections in three pregnant women-United States, April-May 2009. MMWR Morb Mortal Wkly Rep 2009; 58: 497-500.

4. Considerations regarding novel $\mathrm{H} 1 \mathrm{~N} 1$ flu virus in obstetric settings. Centers for Disease Control and Prevention Web site. http://www. cdc.gov/ h1n1flu/guidance/obstetric.htm. Updated July 6, 2009. Accessed August 24, 2009.

5. Jamieson DJ, Honein MA, Rasmussen SA, Williams JL, Swerdlow DL, Biggerstaff MS, et al. Novel Influenza A (H1N1) Pregnancy Working Group. H1N1 2009 influenza virus infection during pregnancy in the USA. Lancet 2009; 374: 451-8.

6. Hospitalized patients with novel influenza A (H1N1) virus infectionCalifornia, April-May, 2009. (Centers for Disease Control and Prevention (CDC)) MMWR Morb Mortal Wkly Rep 2009; 58: 536-41.

7. Centers for Disease Control and Prevention (CDC). Novel influenza A (H1N1) virus 191 infection in three pregnant women - United States, April-May 2009 [published erratum 192 appears in MMWR Morb Mortal Wkly Rep 2009; 58: 541]. MMWR Morb Mortal Wkly 193 Rep 2009; 58: 497-500.

8. Louie JK, Acosta M, Jamieson DJ, Honein MA. Severe 2009 H1N1 influenza in pregnant and postpartum women in California; California Pandemic (H1N1) Working Group. N Engl J Med 2010; 362: 27-35. Epub 2009 Dec 23. [CrossRef]

9. Tanaka T, Nakajima K, Murashima A, Garcia-Bournissen F, Koren G, Ito S Safety of neuraminidase inhibitors against novel influenza A (H1N1) in pregnant and breastfeeding women. CMAJ 2009; 181: 55-8. [CrossRef]

10. Centers for Disease Control and Prevention (CDC). Pregnant women and novel influenza A (H1N1) virus: considerations for clinicians. (http://www.cdc.gov/h1n1flu/clinician_pregnat.htm) (accessed December 28, 2009)

11. Turkish Ministry of Health, H1N1 report. (19.1.2010) http://www. grip.gov.tr. 